\title{
Urban-Rural Migrants and Commodification of Rural- Coastal Villages on a Touristic Island: A Case Study of Woljeong-Ri on Jeju Island, Korea
}

\author{
Hye-Jin $\mathrm{Bu}$
}

Department of Geography Education, College of Education of Jeju National University, 102 Jejudaehakno, Jeju-Si, Jeju Special Self-Governing Province, Korea

hyejin.bu79@gmail.com

Publication Information:

Received 27 September 2016, Accepted 21 June 2017, Available online 28 June 2017

doi: 10.21463/jmic.2017.06.1.02

\section{Abstract}

Recently a significant population migration to rural areas has been occurring in relation to both rural and urban areas in Korea. This urban-rural migration is characterized by region. On Jeju Island the number of Return Non-Farm Households provides the overwhelming majority, unlike other regions. This has partially been the result of the geographical location and tourism industry of Jeju Island. This migration tendency is causing a transformation in the rural space. Thus this paper aims to describe and determine how an increase in urban-rural migrants causes commodification of a ruralcoastal village, both in terms of the reasons and the processes in order to understand rural spatial transformation by inmigrants. As a result, service activities by in-migrants in Woljeong village are associated with commodification of the village in terms of consumption of the village landscapes. This includes the ocean view and sales of farm lands and houses. Commodification of the village has overheated commercialization of the village space and competition in the same field of business. Finally, a spatial division between the existing 'spatial practices' of the village natives and the commercialized place of new stakeholders has occurred. This means that the rural space and identity have transformed in Woljeong-Ri.

\section{Keywords}

Urban-rural migrants, commodification, spatial transformation, Worljeong-Ri, Jeju Island 


\section{Introduction}

Recently rural areas in Korea have been experiencing a huge population migration from urban areas. Urban-rural migration has been occurring across the country and the number of these migrants has been increasing for the last 5 years. Now that the total population of urban-rural migration has reached 10,075 households (17,464 people) in 2011 and 329,369 households (486,638 people) in 2015 . This represents an approximately thirty-three-fold increase. It should be noted that urban-rural migration can be classified into two different types of households in Korea; Return Farm Household and Return Non-Farm Household 1 . The number of Return Non-Farm Households is considerably bigger than that of Return Farm Households. The number of nationwide Return Farm Households as of 2015 is 11,959 households while the number of Return Non-Farm Households is 317,409 households (Korea National Statistical Office, 2016).

Such urban-rural migration has influenced the local population in several ways. In fact, according to the 2015 census, the province and the city with the highest net influx of population are Sejong-Si $(29.0 \%)$ and Jeju Special Self-Governing Province $(2.3 \%)^{2}$ (Korea National Statistical Office, 2015). Particularly in Jeju Special Self-Governing Province which is the biggest island in Korea, has had the smallest urban-rural migration among the 17 providences and metropolitan cities, however, it has still been contributing to a recent increase in the local population ${ }^{3}$. As of 2015 approximately 7,537 households (390 of them are Return Farm-Household) had moved and settled down on Jeju Island. This has led to the current total population of Jeju Island reaching 624,067 people. In view of this, the population of Jeju Island had remained at 550,000 up to 2011 with the net migration growing since then. The latest major population increase has occurred within the last 5 years and this has been unprecedented (Bu, 2015).

The most significant characteristics in current urban-rural migration are that of the young generation, with higher education backgrounds. Such an increase in the young in-migrants have brought changes to the rural areas which used to be summarized as a depopulation and aging population together with the underdevelopment of the population (Kim, 2009). Migrants from the urban areas have influenced the economy, culture, welfare in a positive way for the rural areas (Hwang et al., 2011). On the other hand, stable work other than agriculture is needed, since engaging in stable work affects young in-migrants' safe settlement. In fact, not only Return Non-Farm Households but also Return Farm Households point out that earning enough income in rural areas, particularly for Return Non-Farm Households that obtain 'income source for livelihood' is the most important factor in the preparation step for migration to rural areas (Hwang et al., 2011). In other words, sustainable maintenance of livelihood (sustainable and stable income sources) works as a decisive factor in their settlement.

In that sense, advantages of place being offered by Jeju Island as a touristic island seem to be practical. As Oh et al. (2013) mentioned, many of Return Farm Households have been remodeling available rural buildings for their commercial facilities. And such Return Farm Households with commercial facilities have been increasing every year (Bu, 2015).

Considering that the tourism sector accounts for about $24 \%$ in GRDP as of 2012 and its weight has been steadily increasing (Jeju Tourism Organization, 2014), this is not an unexpected result. In point of fact, extension of low cost airlines has contributed to the time distance and cost of flight even though Jeju Island is the most distant island from the peninsula. Furthermore, it has made the domestic Seoul-Jeju route the busiest in the world (Leff, n.d.). Given these circumstances, tourism and travel-related services, as new work, might have been highly attractive for urban migrants to rural Jeju. 
A great deal of various urban people with a range of educational and professional backgrounds decide to move to rural areas as they commonly long for country life and well-being in idyllic countryside locations, away from the busy and competitive life in cities (Lee and Park, 2012). As to the reason for migration, people who moved to rural Jeju have the same idea as the people who settled down in the countryside of other regions (Kim and Choe, 2011). It should be noted that even though migration to rural areas is an individual decision, it results in significant changes in rural society and economy, as well as the landscape (Bu, 2015; Gosnell and Abrams, 2011). For example, service works of in-migrants, which is usually accompanied with the construction of cafés and restaurants, make it a major contrast to native rural villagers. This has resulted in a huge change in rural landscape on Jeju Island. In particular, a vast population of rural villages on Jeju Island has been engaging in agriculture, fishery ${ }^{4}$ with the advantage of geographical site. Many of them were born, grew up and continue farming in these villages. Thus, it is predicted that in-migrant activities can affect village natives' spatial practices and the combination of them will create new rural space.

Therefore, this research aims to describe and determine commodification of rural-coastal village Woljeong-Ri on Jeju Island in order to look into rural spatial transformation by in-migrants. The study area, Woljeong-Ri, is the place in which diverse in-migrants have been changing the village landscape. Process and representation of commodification of the village, and its significant results will be documented in this paper, furthermore, a difference in between the consciousness of the village nature of the native villagers and the in-migrants will be also determined.

\section{Methods}

This study aims to determine commodification of Woljeong-Ri, rural-coastal village, and its major results by in-migrants. For that, the author has applied several methods; collecting and analyzing relevant documents, census data, interviewing the native villagers and in-migrants, participation and observation to regular cleaning activity of the in-migrants and mapping of locations in service activity construction.

Firstly, the author collected and analyzed relevant articles from magazines and newspapers to comprehend the circumstances of the village. And the census of registration population of Jeju Special Self-Governing Province and national population census were used to figure out population changes of the village. Furthermore, statistic data of the accommodation facilities of the province were also applied to verify an increase in tourism service facilities and the distribution of those facilities in the rural areas of the island.

Secondly, the interview of 10 native villagers was carried out with the purpose of understanding their thoughts about the village landscapes i.e. land, sea and beach, and emergence of commercial facilities in the village. From the interviews of in-migrants, reasons or motivation for migration to the village can be determined. Their new work and construction of service facilities for economic activity and the relationship with other in-migrants in the village were mainly questioned. Participation and observation of regular cleaning activities of the in-migrants were carried out for a month during October 2015, in order to look into their consciousness of the village landscapes and its reflection on their activity. The author freely talked to in-migrants about daily life, tourists and their work through semi-structured interviews. This has led the author to sometimes face the native villagers' real responses to in-migrants and their activities while participating in these interviews and the cleaning activity. 
Thirdly, in order to look into commodification of rural space and its results the author walked around the entire village and counted all the commercially used constructions, mapping their distribution. Moreover, newly constructed car parks, buildings under construction for commercial use and farm lands purchased and altered to commercial use by inmigrants were also investigated.

\section{Urban-rural migration and rural changes in a local context}

Recent urban-rural migration in Korea has similarities to that of American and European countries in terms of the pursuit of lifestyle; well-being, country life, ecological life and idealized life. At the same time, push factors include difficulties living in cities, such as increased living cost and environmental negatives caused by overpopulation (Oh, 2012). However, as many academic research results point out, most of the urban-rural migrants weigh the value of living in the countryside which has an abundancy of nature, well-being in idyllic surroundings and a relaxing life (Kang, 2010; Kim and Choe, 2011; Lee and Park, 2012; Ma et al., 2015; Oh, 2012; Park et al., 2007). This shows that city people's recognition of the countryside has changed in a positive way. Such a cognitional change has been reflected not only in baby boomers and retirees' rural lives after retirement (Seo, 2010; Yoon et al., 2005) but also in the movement of the young generation between the 30s and 50s, with higher education backgrounds (Kang, 2010; Lee and Jeon, 2015; Ma et al., 2015; Oh, 2012; Ryu, 2011). This population movement across the entire country differs from that during IMF crisis 5 in the perspectives of migrants' educational background and economical base (Jyung, 1998; Ma et al., 2015; Oh, 2011) and is the process of counter-urbanization.

It should be noted that urban-rural migrants are usually classified into two types in Korea; Return Farm Household and Return Non-Farm Household 6 . This way of classification is actually associated with the rural revitalization in three perspectives. In other words, they are 1) depopulated and aged rural population, underdeveloped rural areas and declined local agriculture need to be improved, 2) policy makers believe that an increase in urban-rural migration contributes to rural improvement, and 3) in particular Return Farm Households play the main role in the local agriculture (Bu, 2015). Thus, Return Farm Households are supported by governments in terms of both economical and agricultural education. For that reason, many of the academic research papers about urban-rural migrants contain political implications to sustainably facilitate Return Farm Households' settle down. In particular, stable work/jobs and building relationship with the locals through participation in the local community activities are required to settle down permanently in rural areas (Hwang et al., 2011; Kim, 2009; Ma et al., 2015). This research presupposed that an increase in urban-rural migrants influences the countryside in positive ways and such optimism is shown actually in many policies for urban-rural migrants. However, each local has their own circumstances and current policies do not cover those differences by the locals (Lee and Park, 2015).

A range of changes by an increase in urban-rural migrants such as rural gentrification (or greenfication) (Nelson and Nelson, 2010; Smith and Phillips, 2001), changes in land use and landscape (Bu, 2015; Cadieux and Hurley, 2011), changing rurality (Eom, 2012; Halfacree, 2006a) have been reported. These transformations are associated with postproductivist or multifunctional countryside (Gosnell and Abrams, 2011) by rural restructuring (Woods, 2005). In the process of such transformation, commodification of rural places is seen in forms of consumption of the rural landscapes and goods and services that represented idealized rurality (Tonts and Greive, 2002). In addition to, images of 
idylls can help contribute in attracting tourists, second-homebuyers and in-migrants. These new stakeholders lead the development of idealized forms of the landscape and communities (Tonts and Greive, 2002).

This is exactly what is reflected currently in rural Korea. As Eom (2012) pointed out, only about $35 \%$ of rural residents are engaging in agriculture and the figure has been decreasing in Korea. The significant reasons for this is due to agricultural restructuring in the world trade environment. In such changing circumstances, rural tourism and the sextic industry based on the multifunctionality of agriculture have been emphasized in farm households' stable income (Bang, 2005; Park et al., 2014; Park, 2003). However, urban-rural migration is characterized by region in Korea. For example, according to Lee and Jeon (2015), Gyeongbuk Province is the place where quite a number of the Return Farm Households return. About $73 \%$ of these migrants settled down in the northern areas and midlands of the province, while coastal areas were avoided. It is because of this that rural towns such as Sangju and Yoengju in the northern part are so famous for their agricultural products. New farm households engagement in the cultivation of local famous agricultural products. In the case of Jeju Isand, Bu $(2015,2014)$ showed that the number of Return Non-Farm Households is far more than that of Return Farm Households. Furthermore, genuine migration motivation for the Return Farm Household is not agricultural but escape from a competitive city life (Kim and Choe, 2011). This has resulted from the geographical location and tourism industry of Jeju Island, as a distant touristic island (Yoon, 2014). These differences in in-migrants' character can be interpreted as a consequence of the existing 'spatial practices' (Halfacree, 2007). 'Spatial practices' means "the actions that 'secrete' a particular society's space, facilitation both material expression and societal reproduction" (Halfacree, 2007).

Thus, different migration tendencies imply not just a necessity of policies based on local diversity, but also its unpredictable and various spatial transformations by local diversity. Because rural "space is something created in a whole series of forms and at a whole series of scales by social individuals" (Halfacree, 2006b).

\section{Population Change ${ }^{7}$ and Commodification of a Rural-Coastal Village Woljeong-Ri}

\section{Beach aspects and difficulties in agriculture of Farm households in this rural-coastal village}

Weoljeong-Ri is a small rural-coastal village which is located in the northeastern side of Jeju Island at a distance of about $30 \mathrm{~km}$ from Jeju City (Fig. 1). The village meets the sea and as a consequence of this it has developed its fishing ground and beach aspects ${ }^{8}$. Thus most of the villagers have been engaging in both agriculture and fishery. In particular, fishery has been carried out by women divers, who catch seafood such as conch-shell, abalone and gelidium within the fishing grounds. Meanwhile farm households in Woljeong-Ri have been mainly cultivating garlic, carrots and spring onions due to the sandy landscape. The beach in Woljeong-Ri, is actually called "Hanmosal", which means huge amount of sand in the Jeju dialect. Although it has developed sand dunes along the beach, wind-blown sand in the winter season has directly affected the villagers' lives; sandy land and pileup of sand about $4 \sim 5 \mathrm{~cm}$ in houses near by the beach. This wind-blown sand has led the villagers to the construction of a sand preventing wall, along the beach in 1950 (Seo, 1987). Approximately $80 \%$ of the villagers have continued to farm and catch seafood before in-migrants moved to the village. 
According to Seo (1987), sandy soil had resulted in the low productivity of agriculture. Farmers have had difficulties in the cultivation of cash crops. Furthermore, in the past, the number of the farm households was more than the current number. Agricultural labor force per household was about $4 \sim 5$ people and the size of the farm plot was about 0.4 ha, on average. As a result, people had left the village or they had been in debt. This in turn has caused many empty houses.

This kind of villager response seems to be opposite to that of the outsider. City people were attracted to the beach 'Hanmosal' while the villagers deemed the beach as a beautiful but useless land. The villagers could have utilized the beach as a tourism attraction but they did not. Meanwhile rich city people had already purchased shore plots of the village for investment in 1990 (Hong, 1990). Even though direct investment of buyers had not immediately happened until 2011, the villagers allowed the construction of sea-wind power generators in the beach with rewards in 2006.

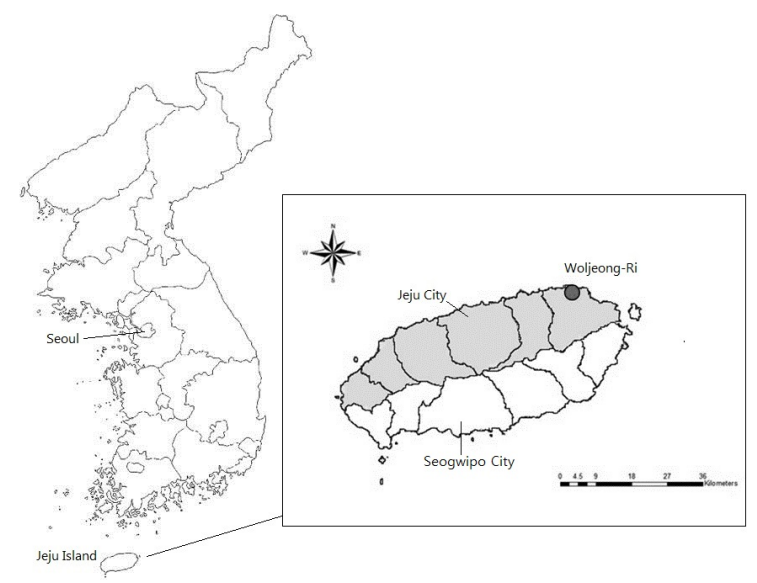

Fig 1. Study area: Location of Woljeong-Ri

\section{Migration Increase and Service Works in the village}

In comparison to the villagers, the beach was the major attraction of the village for many of the in-migrants, who initially moved to the village. In addition, empty houses and abandoned farmlands have been a good factor for stable settlement.

Table 1 shows changes in village population and households in Woljeong-Ri. Population and households have decreased up to 2011 and tended to increase since then. However, a temporal fall in population and households occurred in 2013. During 2011 the number of population and households are the lowest until 2015, where 36 people and 70 households are newly added. In consideration of this the number of births during this period has remained unchanged with the newly added population due to in-migrants. And migration to the village slightly decreased the rate of the population aged 60 years or over from $30.5 \%$ (2011) to $30.1 \%$ (2014) in Woljeong-Ri. In other worlds, the majority of in-migrants are couples of husband and wife, singles, and their ages range from 20 s 50 s. 
Table 1. Changes in population and household in Woljeong-Ri

\begin{tabular}{|l|l|l|}
\hline \multicolumn{1}{|c|}{ Year } & \multicolumn{1}{c|}{ Population (people) } & Household (households) \\
\hline 2005 & 790 & 303 \\
\hline 2010 & 713 & 288 \\
\hline 2011 & 694 & 282 \\
\hline 2012 & 713 & 296 \\
\hline 2013 & 692 & 296 \\
\hline 2014 & 720 & 329 \\
\hline 2015 & 730 & 352 \\
\hline
\end{tabular}

Source: Jeju Special Self-Governing Province (2015, 2014, 2013, 2012, 2011, 2010, 2005)

It is in the service sector that the vast majority of in-migrants in Woljeong-Ri chose for their stable livelihood.

Accommodation facilities such as guesthouses, recreational pensions, restaurants and cafés are newly opened by these in-migrants. Even though they have various career and educational backgrounds, most of in-migrants run these service facilities in advantages of the existing tourism infrastructure such as Olle trail ${ }^{9}$. Cafés and restaurants are lining up along the coastal road facing the beach. Exotic buildings of cafés with open rooftops and whole glasses, embrace the ocean views. This coastal road is now called 'Café Road' and has become a popular place for tourists to visit. The beach of Woljeong-Ri is widely known as an exotic shore with wind power generators. It is introduced by several tour guide books, Jeju tourism sites and even on individual blogs as an exotic shore. However, more visitors have stopped at the village which has in turn caused more parking problems to occur ${ }^{10}$. As a result, the village paved wide the sandy landscape beside the beach for free car parks.

Behind the 'Café Road', there are numerous accommodation facilities located. Early in-migrants remodeled old farm houses to utilize them as guesthouses or for recreational pensions. Recent in-migrants tend to newly build two or threestory buildings for their business. Furthermore, in the beginning those commercial facilities have been created nearby the beach and along the coastal road. Now they have been expanded into the village and the number of these facilities has been also increasing year by year (Table 2).

Fig. 2 shows the distribution of these commercial facilities in Woljeong-Ri. Commercial facilities are intensively located along the coastal road. This is due to the ocean views and wide parking spaces nearby the beach which are favored by visitors' for convenience. Given these circumstances, there are no available spaces on the 'Café Road' for new shops anymore. In addition to that, the price of land on the 'Café Road' has sharply risen and has now reached 10 million Won per $3.3 \mathrm{~m}^{2}$. Only 4 years ago village houses in Woljeong-Ri were 30 million $\sim 40$ million Won, and now they cost as much as the capital of Korea, Seoul. The average price of apartments in Seoul is about 18 million Won per $3.3 \mathrm{~m}^{2}$.

Moreover, only two buildings belong to the native villagers and the rest of buildings are owned by in-migrants on this 'Café Road'.

The village circumstances also influence the native villagers. Out-migrated young villagers have returned to the village and opened their own shops such as restaurants and convenience stores. Interestingly, convenience stores were once 
the avoided business item by urban-rural migrants in the village. This was because they believed that the sales of cafés and restaurants can be affected by convenience stores. Currently, however, two convenience stores are run by the native villagers competing with each other on the 'Café Road'.

Table 2. Distribution of accommodation facilities by village in Gujwa-Eup ${ }^{11}, 2015$

\begin{tabular}{|c|l|l|l|l|l|l|l|l|l|l|l|l|}
\hline Village & $\begin{array}{c}\text { Wol- } \\
\text { jeong }\end{array}$ & \multicolumn{1}{|c|}{$\begin{array}{c}\text { Kim- } \\
\text { nyeong }\end{array}$} & $\begin{array}{c}\text { Dong- } \\
\text { bok }\end{array}$ & $\begin{array}{c}\text { Haeng- } \\
\text { won }\end{array}$ & $\begin{array}{c}\text { Han- } \\
\text { Dong }\end{array}$ & $\begin{array}{c}\text { Pyeong- } \\
\text { dae }\end{array}$ & Sehwa & $\begin{array}{c}\text { Sang- } \\
\text { do }\end{array}$ & $\begin{array}{c}\text { Hado } \\
\text { Jong- } \\
\text { dal }\end{array}$ & $\begin{array}{c}\text { Song- } \\
\text { dang }\end{array}$ & $\begin{array}{c}\text { Deok- } \\
\text { cheon }\end{array}$ \\
\hline $\begin{array}{c}\text { The number of } \\
\text { facility }\end{array}$ & 30 & 11 & 8 & 9 & 10 & 16 & 22 & 5 & 32 & 11 & 18 & 3 \\
\hline Village population & 739 & 2,887 & 701 & 1,094 & 1,285 & 1,478 & 1,999 & 375 & 1,855 & 1,281 & 1,011 & 279 \\
\hline
\end{tabular}

Source: Field research, Jeju Special Self-Governing Province (2014) and Jeju Accommodation Map. Most accommodation is located in Hado among the 12 villages. However, in view of the total population of the village, it is in Woljeong (Ri) where the facilities are the most intensively located per person.

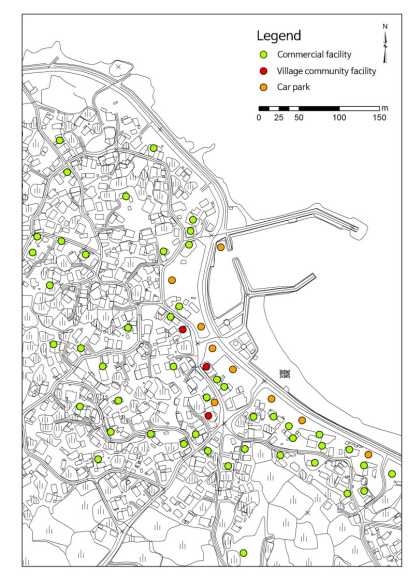

Fig 2. Distribution of commercial facilities in Woljeong-Ri

Other native villagers remodeled their houses as an accommodation facility or built new buildings just like the inmigrants did. Therefore, more commercial facilities are causing severe competition in the same field, and land use has been also highly altered. Farm lands, abandoned useless land as well as sand dunes have been used for the construction of these new buildings. Furthermore, tall buildings on the shore now block the ocean view from both the entrance of the village and inside the village.

\section{Who sells 'our beach' and 'our village'?}

Woljeong-Ri is one of the typical rural-coastal Jeju villages. It is characterized by small detached farm houses with low roofs and stone walls that are gathered in a huddle. Roads and all the farm houses are surrounded with basaltic stone 
walls. The paths the villagers always use are narrow and paved in cement. In the open space near the sea, a small port and a public building for women divers, a building for the Village Fisheries Cooperative are also located. The beach adds some uniqueness to Woljeong-Ri.

In 2015 about one million visitors stopped at Woljeong-Ri. This figure includes both tourists who enjoyed leisure sports in the sea and visitors who only took photos of the beach or drank coffee in cafés. Most of the visitors are fond of taking picturesque photos with the background of the rural landscape and the beach.

Fortunately, this kind photography and swimming in the sea ${ }^{12}$ are free of charge activities. Leisure sports such as surfing and canoeing are newly introduced activities within the sea. Similarly riding an electronic two-wheel board inside the village is getting popular among the visitors. These types of tourism activities indicate that tourists currently pursue the participation of adventurous experiences rather than sightseeing activities in Woljeong-Ri. As Woods (2005) mentioned, the pursuit of these activities also contributes to the commodification of rural villages as a place of adventure.

A range of souvenirs such as smartphone cases with a picture of Woljeong Beach on their cover, postcards and accessories are made and sold by in-migrant sellers. Even a major cosmetic company is now selling nail polish with the name 'Jade blue Woljeong Beach'. City people who have visited and experienced Woljeong-Ri can purchase these products from on and offline shops. Images of the village landscape are represented in a form of commodities and these commodities are sold to city people.

Enjoying the ocean views on the open roof top of cafés is also in line with the commodification of the village landscapes. All the cafés on the 'Café Road' have been designed in order to gain pleasure from the ocean view. The cost of enjoying these views is included in the price of the coffee. Prices of beverages are 1.5 2 times higher than those of ordinary cafés in Jeju City. Moreover, remodeled farm houses for guesthouses and cafés are reflected in idealized rural images and are where guests enjoy timeless rural beauty.

As a result, Woljeong-Ri and Woljeong Beach have become a local brand. In the process of commodification of the village landscapes, new stakeholders are added. Ironically, these new stakeholders were not directly related with the maintenance of these rural landscapes. In other words, up until now, only the native villagers have been devoted to the maintenance of the farm lands, village paths and the sea. Furthermore, in Korea the sea belongs to the state but the exclusive usage right for livelihood and community interests is preferentially given to the villagers. The sea is managed and used by the villagers as the village common property(An, 2007). Therefore, they can maintain the beach in the way that they want, without exploitation. Current commodification of the village landscape does not include their timeless qualities associated with the rural landscapes and the efforts that the native villagers have made. The native villagers' perception of this is negative. "Only in-migrants make money by selling our beach and our village". This shows how deeply deprived they commonly feel. 


\section{Conclusion}

The aim of this paper has been to describe how an increase in urban-rural migrants causes commodification of a ruralcoastal village, both in terms of the reasons and the processes in order to understand rural spatial transformation by inmigrants.

A vast number of urban-rural migrants who move to rural areas of Jeju Island choose tourism and related services as their livelihood, using the existing tourism infrastructure that Jeju Island has developed, as a touristic island. In-migrants usually run cafés and accommodation facilities which do not require any particular skills even though they have various educational and career backgrounds. This tendency has increased the number of commercial facilities in rural areas on Jeju Island. Woljeong-Ri, the study area, is a rural-coastal place, where such commercial facilities are densely located.

However in contradiction the two sides of the village beach played the decisive role in the background where in-migrants have opened commercial facilities relating to tourism in Woljeong-Ri. This village is one of the typical traditional villages of the Island. But the beach has affected agriculture in aspects of low agricultural productivity and useless sandy farmlands for long periods of time. As a result, many of the villagers left their home and many houses and farmlands have remained empty and abandoned. However, these negatives became the significant settlement factors when migrants from urban areas settled down in the village. In addition to, the beach is actively commoditized by owners of cafés and restaurants at the moment. This commodification of the beach has worked as a factor in these commercial facilities, causing increases in the commercialization of the village space.

Current commercialization of the village has expanded inside the village through altering empty farm houses and abandoned farmlands as well as sand dunes in commercial facilities. The land value and competition of the same field has been overheated, in a similar way to cities. Fundamentally the expansion of the commercial spaces in the village is a result that has been accompanied by the commodification of farm houses and farmlands. Furthermore the commodification of the village is practiced not only in a form of direct sales of houses and lands, but also in various forms of adventurous tourism activities and sales of goods that represent the village landscapes, which in addition enjoy the ocean view. Thus expansion of commercial space in the village is currently inevitable, as long as the commodification of the village is continued. These new spatial activities have led to a spatial division between the existing 'spatial practices' of the village natives and the commercialized space of new stakeholders in the village space.

Meanwhile, a vast majority of the village residents are native villagers that have been engaging in agriculture and fishery. Their response to the commodification and the commercialization of the village is either to feel deprived or to turn into a business-like way, as in-migrants. In particular, the last means that the native villagers directly participate in the commodification and the commercialization of the village can deepen these phenomena.

Therefore, it is clear that not only the native villagers including the out-migrated villagers (who sold their lands and houses) but also the in-migrants, are directly participating in the commodification of Woljeong-Ri. Meanwhile, tourists and visitors are indirectly influencing changes in the rural landscapes by using rental cars and purchasing the ocean view. Furthermore, it is undeniable that this commodification and commercialization of the village has resulted in enormous changes in both the rural space and the rural identity in Woljeong-Ri. 


\section{Acknowledgements}

This work was supported by the National Research Foundation of Korea Grant funded by the Korean Government.(NRF2014S1A5B5A01011925)

\section{Endnotes}

1. According to the Korean National Statistical Office, Return Non-Farm Household (people) is defined as "people who migrated to rural areas for the purpose of enjoying countryside life. However, people who have particular jobs such as office workers and teachers are excluded".

2. Meanwhile Seoul and Deajeon City record the highest net outflow of population in each of $-1.4 \%$.

3. In fact, the number of births had decreased 2000 2014. Meanwhile the number of deaths had increased (Kim and Choe, 2011).

4. In all the rural-coastal villages on Jeju Island, many of women have been taking part in households' economic activities mainly as women divers. Refer to Kim (2016) and Ko et al. (2010) for more information about Jeju women divers.

5. During the IMF crisis in Korea, many of the city people moved to rural areas due to unemployment in the cities. As a result, demand on agricultural education by them had sharply increased (Jyung, 1998).

6. Several researchers (Kang, 2010; Suh and Byun, 2000) managed to classify in-migrants into three types; U-turn, J-turn, I-turn. Each type of the classification includes homes and moving path of the in-migrants, their experiences in agriculture as well. This research is about agricultural education for urban-rural migrants, and migrants' needs and satisfaction are up to their previous experiences of agriculture and countryside life.

7. Refer to Bu (2015) to see changes in total population of Jeju Island.

8. The locations of village fishing grounds and beaches are different. The fishing ground is located on the far most western part of the village.

9. According to some in-migrants who are running those shops, they do not need any special skills. Moreover, tourists always visit as long as they run the service facilities.

10. According to many villagers, they commonly pointed out that they have experienced parking troubles. This was because visitors usually use rental cars and park on the village paths or in front of someone's house.

11. 'Eup' refers to a lower administrative divisions that consists of rural areas in Korea. As shown on Fig. 1, there are 8 Eups and 2 Myeons (also a lower administrative division referring to rural areas) except for the two cities on Jeju Island. Gujwa-Eup of Table 2 is one of the 8 Eups and is made of the 12 villages.

12. Domestic sea belongs to the state as a public surface of water and the users of the beach do not need to pay for that. 


\section{References}

An, M.-J., 2007. The Communa-Fishing And Resources Rights of Coastal Village Women: A Case Study of the Women Divers' Work in Jeju Island. J. Local Hist. Cult. 10, 151-197 (in Korean).

Bang, H.-Y., 2005. Appropriate Rural Activation Policies. Rev. Archit. Build. Sci. 49, 33-37 (in Korean).

Bu, H., 2015. Rural Change by increase in Urban-to-Rural Migrants in Jeju Island. J. Korean Assoc. Reg. Geogr. 21, $226-241$ (in Korean).

Bu, H., 2014. A "Mainland" on the Island?: an Increase in Non-Agricultural Migrants and Their Adaptation to Rural Communities - A Case Study of Namwon Town, Seogwipo City, Jeju Self-Governing Province, in: 2014 Summer Conference of the Korean Rural Tourism Associati. the Korean Rural Tourism Association, pp. 113-127 (in Korean).

Cadieux, K.V., Hurley, P.T., 2011. Amenity migration, exurbia, and emerging rural landscapes: global natural amenity as place and as process. GeoJournal 76, 297-302.

Eom, E.-H., 2012. Rurality in transition and the responses of local in-migrants' organization: case study on Pusan Refarm School. J. Rural Soc. 22, 133-172 (in Korean).

Gosnell, H., Abrams, J., 2011. Amenity migration: Diverse conceptualizations of drivers, socioeconomic dimensions, and emerging challenges. GeoJournal 76, 303-322. doi:10.1007/s10708-009-9295-4

Halfacree, K., 2007. Trial by space for a " radical rural ": Introducing alternative localities, representations and lives. J. Rural Stud. $23,125-141$. doi:10.1016/j.jurstud.2006.10.002

Halfacree, K., 2006a. From dropping out to leading on ? British changing rurality. Prog. Hum. Geogr. 30, 309-336.

Halfacree, K., 2006b. Rural Space : constructing a three-fold architecture. Handb. Rural Stud. 44-62. doi:10.4135/9781848608016.n4

Hong, H.-R., 1990. Rising Moon Coastal Village. Mon. Jeju 69-73 (in Korean).

Hwang, J.-I., Choi, Y.-J., Cho, H.-M., Yoon, S.-D., 2011. Rural Migrants ' Community Participation and Relationship With Rural Life Satisfaction. J. Agric. Ext. Community Dev. 18, 729-764 (in Korean).

Jeju Accommodation Map [WWW Document], n.d. URL http://najeju.com/

Jeju Special Self-Governing Province, 2015. 2015 Census of Registration Population of Jeju Special Self-Governing Province.

Jeju Special Self-Governing Province, 2014. 2014 Census of Registration Population of Jeju Special Self-Governing Province.

Jeju Special Self-Governing Province, 2013. 2013 Census of Registration Population of Jeju Special Self-Governing Province.

Jeju Special Self-Governing Province, 2012. 2012 Census of Registration Population of Jeju Special Self-Governing Province.

Jeju Special Self-Governing Province, 2011. 2011 Census of Registration Population of Jeju Special Self-Governing Province.

Jeju Special Self-Governing Province, 2010. 2010 Census of Registration Population of Jeju Special Self-Governing Province.

Jeju Special Self-Governing Province, 2005. 2005 Census of Registration Population of Jeju Special Self-Governing Province.

Jeju Tourism Organization, 2014. Jeju Tourism Market Trend (in Korean).

Jyung, C.-Y., 1998. Current Status and Directions of Agricultural Training for the Unemployed Willing to Return to the Farm. J. Korean Agric. Educ. 32, 1-26 (in Korean).

Kang, D.-K., 2010. Present Status and Policy Implication of People Return to Farm and Rural Areas. J. Agric. Ext. Community Dev. 17, 743-771 (in Korean). 
Kim, J., 2009. What can local governments do to help people returning to rural areas? J. Agric. Ext. Community Dev. 16, 533-556 (in Korean). Kim, M.-Y., Choe, H., 2011. Internal Migration to Jeju-Current status and Prospects. TAMLA MUNHWA 50, 39-78 (in Korean).

Kim, S., 2016. Jeju Island Women Divers 'Association in South Korea Jeju Island Women Divers' Association in South Korea : A Source of Social Capital. Asian J. Women's Stud. 9, 37-59 (in Korean).

Ko, J., Jones, G.A., Heo, M., Kang, Y., Kang, S., 2010. A fifty-year production and economic assessment of common property-based management of marine living common resources : A case study for the women divers communities in Jeju, South Korea. Mar. Policy 34, 624634. doi:10.1016/j.marpol.2009.11.013

Korea National Statistical Office, 2016. Census of Urban-Rural Migration.

Korea National Statistical Office, 2015. Internal Migration in 2015.

Lee, C.-W., Jeon, J.-H., 2015. Regional Characteristics of Urban to rural migration in Gyeongbuk Province. Goegraphical J. Korea 49, 73-88 (in Korean).

Lee, C.-W., Park, S.-H., 2015. Problems and Improvements of Urban-to-rural Migration Policy in Gyeongbuk Province. J. Korean Geogr. Soc. 50, 659-675 (in Korean).

Lee, M., Park, D.-B., 2012. The Typology of Urban-Rural Migration and Its Implication. J. Agric. Ext. Community Dev. 19, 1137-1170 (in Korean). Leff, G., n.d. The 15 Busiest Airline Routes in the World. None are in the US or Europe. - View from the Wing [WWW Document]. URL http://viewfromthewing.boardingarea.com/2015/08/29/the-15-busiest-airline-routes-in-the-world-none-are-in-the-us-or-europe/

Ma, S.-J., Park, D., Park, S., Choi, Y., Nam, K., Nam, S.-H., Choi, Y.-J., 2015. A Trend Analysis of Urban-rural Migrants' Background, Economic Activity, and Community Participation. J. Agric. Educ. Hum. Resour. Dev. 47, 1-21 (in Korean).

Mccarthy, J., 2005. Rural geography : multifunctional rural geographies reactionary or radical? Prog. Hum. Geogr. 29, 773-782.

Nelson, L., Nelson, P.B., 2010. The global rural : Gentrification and linked migration in the rural USA. Prog. Hum. Geogr. 35, 441-459.

Oh, S.-H., 2012. Adaption Process of Migration and Reality of Households Heading to Farming. J. Korean Assoc. Reg. Geogr. 18, 101-117 (in Korean).

Oh, S.-H., 2011. Research Trend in Urban-to-Rural Migration: Focusing on Korean Literature from 1996 to 2010. J. Korean Urban Geogr. Soc. 14, 77-90 (in Korean).

Oh, S.-H., Kang, A.-Y., Yang, S.-J., Yi, Y.-K., 2013. A study on the use of unused space realities of Jeju Island, in: Conference Proceeding of the Regional Association of Architectural Institute of Korea. pp. 11-12 (in Korean).

Park, G.-J., Kim, Y.-H., Park, J.-Y., 2007. Migration Preparation and Adaptation to Rural Area of Returning Farmers after Retirement. J. Korean Home Econ. Assoc. 45, 9-21 (in Korean).

Park, J.-H., Hwang, J.-H., Lee, S.-W., 2014. The effect of the 6th industricalization in agriculture on farm and off-farm income. J. Korean Soc. Rural Plan. 20, 193-208 (in Korean).

Park, S.-H., 2003. Revitalization of Local Economy through Rural Tourism. Plan. POLICY 9, 18-30 (in Korean).

Ryu, H.-R., 2011. Circumstences and types of Urban-to-Rural Migrants in Chungnam. Chungnam Rev. 54, 18-25 (in Korean).

Seo, J., 1987. Weoljeong Village with abundance of “Rock, Sand, Empty Houses.” Mon. Tour. Jeju 80-85 (in Korean).

Seo, S.-B., 2010. The Analysis on Determinants of Rural Area Migration of Baby Boom Generation. Korea Spat. Plan. Rev. 64, 21-37 (in Korean). Smith, D.P., Phillips, D.A., 2001. Socio-cultural representations of greentrified Pennine rurality. J. Rural Stud. 17, 457-469. 
Suh, G.-S., Byun, J.-M., 2000. Development of Long and Short-run Educational Programs for U-turn Farmers. Korean J. Agric. Ext. 7, 137-153 (in Korean).

Tonts, M., Greive, S., 2002. Commodification and Creative Destruction in the Australian Rural Landscape: The Case of Bridgetown, Western Australia. Aust. Geogr. Stud. 40, 58-70. doi:10.1111/1467-8470.00161

Woods, M., 2005. Rural Geography: Progresses, Responses and Experiences in Rural Restructuring. SAGE Publications Ltd, London.

Yoon, S.-B., 2014. New Life, Getting on well altogether in Seogwipo. Planet B Press (in Korean).

Yoon, S.-D., Kang, K.-H., Park, G.-J., Lee, J.-H., 2005. Determinants of migration intention to rural area after retirement among urban residents in Korea. J. Korean Gerontol. Soc. 25, 139-153 (in Korean). 